\begin{tabular}{ll}
\hline \hline MINING AND METALLURGY INSTITUTE BOR & ISSN: 2334-8836 (Štampano izdanje) \\
UDK: 622 & ISSN: 2406-1395 (Online) \\
\hline \hline
\end{tabular}

Vladimir Todorović, Boban Branković, Dejan Dramlic ${ }^{* *}$, Silvana Ilic ${ }^{* * *}$

\title{
A NEW METHOD OF COAL EXCAVATION IN THE COMPLEX NATURAL-GEOLOGICAL CONDITIONS
}

\begin{abstract}
In the underground coal mines in Serbia, nowadays, only the pillar methods of excavation excavations, which all affect the excavation economy.

This paper presents the solution of a new excavation method foreseen for application in the complex natural-geological conditions, which are now in all active coal deposits in the Republic of Serbia.

Keywords: coal, excavation method, production, mechanized excavation
\end{abstract}

\section{INTRODUCTION}

Complexity of the natural-geological conditions for exploitation of our coal deposits requires systematic research work aimed at improving the methods and technologies of excavation, because from this phase depends the technical, safety and economic parameters of the entire underground exploitation system in a particular ledge.

In countries with developed mining, developed underground coal mines, the basic method of excavation of coal seams is the methods of wide foreheads with complex mechanization.

In the complex and different conditions of coal deposits in the Republic of Serbia, numerous and specific technical and technological solutions of the underground coal excavation process were applied, with constant efforts to be adapted to the deposit conditions. The present conditions of the working environment influenced the selection of technological solutions for exploitation, so that in all active mines, the methods of pillar excavation in different variants are applied, which generally do not allow economic exploitation, and the risk of injuries and misconduct of employees on such types of excavation has increased.

The application of mechanized excavation technology on the principle of horizontal and vertical concentration by wide foreheads method only gave the positive technical and economic parameters in some mines and in certain excavation fields.

In order to improve the effects of application the pillar excavations in coal mines in the Republic of Serbia, the need for their rationalization is imposed, as this method of excavation will continue to dominate.

The aim of carried out research in this paper is to give a new approach to the pillar methods of excavation, and within the framework of the underground coal mines in Serbia.

The basic directions of improvement in these analyses are focused on mechani-

\footnotetext{
* PC UCM Resavica

** Institute for Materials Testing - Belgrade

*** FMZ Zaječar
} 
zation the basic technological phases in excavation, especially in the production and loading of the excavation, which is solved by introduction the combined multifunctional machines DH L600 and DH L1200 of the German manufacturer Deilmann-Haniel Mining Systems GmbH.

\section{GENERAL AND SPECIFIC CONDITIONS OF EXPLOITATION}

Based on the collected and processed data, the basic natural - geological conditions in active coal mines are characterized by the following:

- most often these are thick coal seams with frequent thickness changes;

- coal seams are mostly of the complex structures with a smaller or larger share of mullock seams;

- due to intense macro and micro tectonics, the deposits are, as a rule, disruptted by several systems, which formed the excavation fields of irregular shapes and relatively small dimensions;

- in relation to the elements of laying, most of the mines, per depth, belong to the group of mines with the middle depth, and according to the fall they are about inclined and somewhat steep deposits;

- the stability of the mining access areas of excavations is directly related to the physical mechanical properties of the coal seams and associated deposits (with the pronounced participation of clay components) in which conventional sub-systems are applied;

- in terms of wateriness, all deposits, except for the coal deposit "Štavalj", belong to a group of poorly watered mines;

- self-inflammability and explosiveness of coal dust, as well as the natural tendency towards self-ignition, is the general characteristic of all mines, except for the mine Vrška Čuka;
- active deposits are not pronounced methane carriers, except for the deposit of the mine "Soko", where there are some increased methane values, and there are also phenomena of gas and material outbursts.

\section{A NEW PILLAR METHOD OF EXCAVATION WITH THE APPLICATION OF A MULTI-LOADER}

The novelty of a new pillar method of excavation consists in obtaining coal during the construction of the excavation corridor (I phase - excavation in progress), as well as in obtaining the roof and lateral coal in withdrawal (Phase II - excavation in withdrawal), with one of the modern and highly efficient combined machinery for working in the pit, which primarily achieves a large performance during loading.

The excavation, depending on the elevated coal production, can be planned with the use of one machine, and after the completion of the excavation hall (phase I), the same machine works in phase II - the excavation in withdrawal, and so any subsequent excavation, or can be planned using two machines, when the first machine, after completion the excavation hall (phase I), continues to the phase II, and the second machine starts production of the next excavation hall and, upon completion of its construction, works on obtaining roof and lateral coal (phase II - excavation in withdrawal). So, there is:

a) Phase $I$ - excavation in progress, it is actually the construction of a hallway with the known technology of machine building of the corridor (cutting is done with a cutting head, and loading of material with a side spoon in a rake conveyor). It gets important in the use of maximum possible and given pit conditions applicable cross-sectional profile of the excavation hall with increase the 
effects of progression. Therefore, in a shorter time interval, greater progress should be made with the maximum possible profile.

b) Phase II - excavation in withdrawal is a method of obtaining roof and side coal by cutting and mechanically loading a side spoon in a rake conveyor, where the amount of production depends on the thickness of the seam. According to the data, the coal seam is defined with a power of up to $12 \mathrm{~m}$. The width of the pillar between the excavation corridors is determined according to the mine conditions (pressure, ma-nner of sub structuring, adjustment of progression or withdrawal, size of crosssection profile, etc.). Based on the experimental data it should be up to $3 \mathrm{~m}$, and it will be determined in a test work.

In order to obtain roof and side coal, the multifunctional modern loader can be fully expressed with the use of a cutting head, since the coal after the construction of the excavation hall is less compact and it is easier to cut it. The test excavation method will simultaneously be another testing of this multifunctional loader for such a method of excavation. The use of construction tools is especially indicated by the fact that their use is particularly stimulated by the constructive novelty of a multi-loader, so called "click" system, or quick tool change - an average of 10 minutes.

Figure 1 shows the position of the excavation corridor in a coal seam, and Fi-gure 2 shows the principled excavation scheme with the new excavation method.

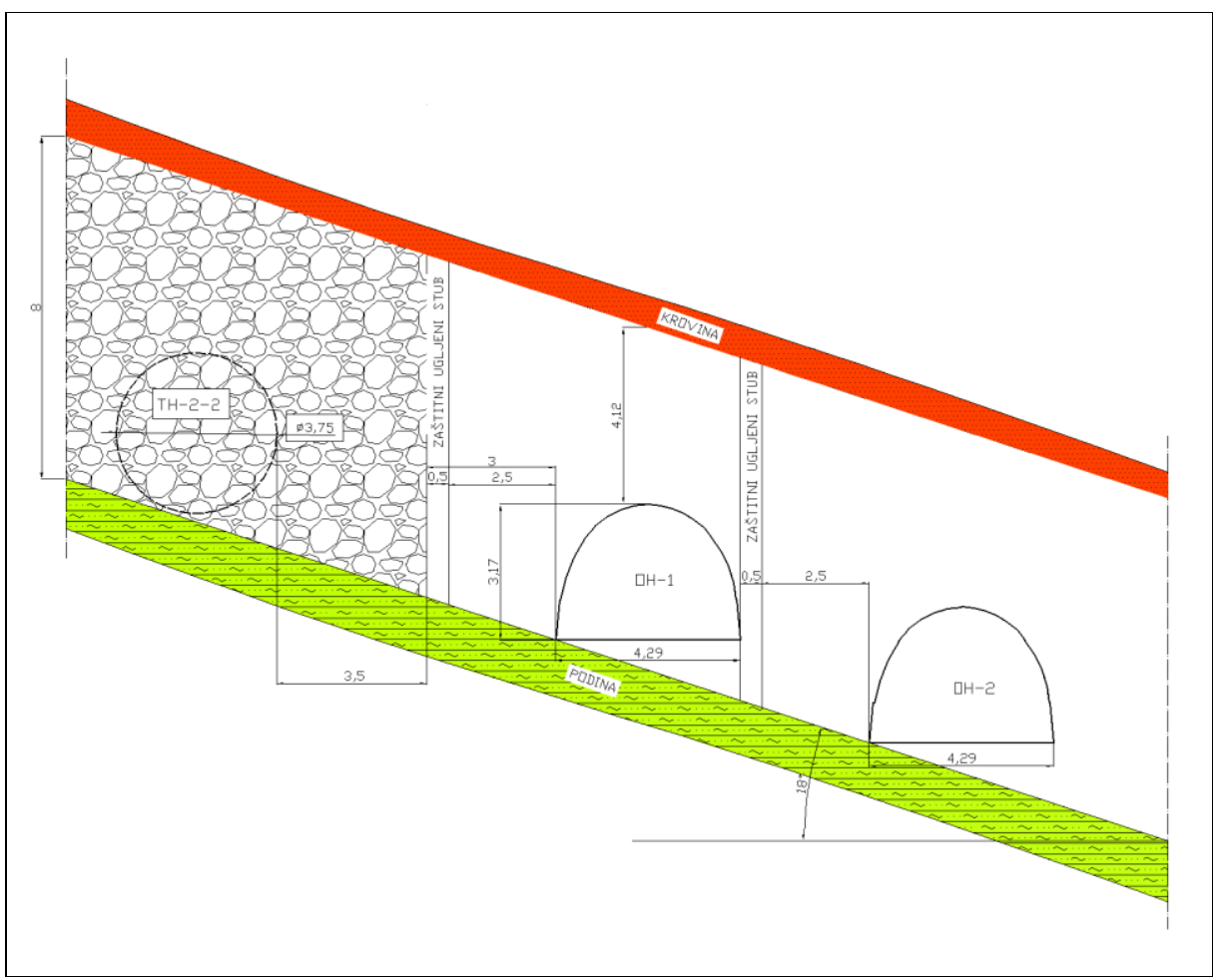

Figure 1 Detail of possible position of the excavation hall $1(\mathrm{OH}-1)$ in a coal seam 


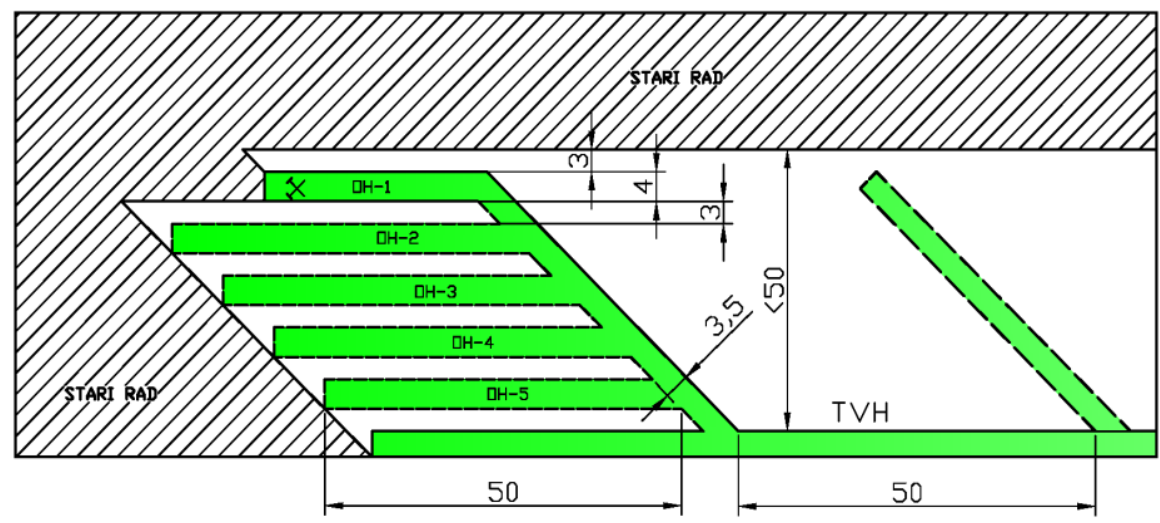

Figure 2 Principal scheme of excavation with a new excavation method

The advantages of the newly designed method are as follows:

- the decline, direction of providing the excavation preparation, but also its length does not significantly affect the possibility of applying of this method, and the change of these elements does not block its further work;

- the geometry of the method can be quickly adjusted to the conditions of seam (by inclination, seam thickness, etc.), and in case of sudden changes (water, methane or self-inflammation) can change;

- there are no special problems related to self-ignition due to the dynamics of excavation, and no special protection measures are foreseen except the usual ones;

- applied mechanization is easy to handle, and above all, it has the possibility of universal application (with the addition of other essential equipment according to the "click" system). The special advantage is that this mining equipment is universal for other applications in the pit, which increases its usefulness;

- the number of engaged labor force compared to the other classical methods is small, and the expected excavation effect is acceptable;

- the multi-loader compensates the lack of combine that it cannot cut below its level;

- the utilization of loading the roof coal is higher, the excavation losses are smaller. Mechanical loading left and right in excavation without input into unprotected space allows it;

- the speed of progress the excavation preparation using the loading rods is increased by more than $50 \%$ in relation to the present, which reduces the accumulation time of pit pressures and "obtaining" the used substrate material, of course, less damaged when extracting or when is under pressure;

- the excavation losses are expected to be smaller. An analysis the geometry of discovery method shows that more coal can be obtained by better excavation planning, e.g. for thicker seams, it is possible to use the method as with the damping from one floor, but also for excavation in two or more belts. With the reduction of the safety pillars between the excavation corridors, the losses are reduced. 
Table 1 shows the comparative analysis of the basic parameters of the "V" methods and the new methods of excavation.

Table 1 Comparative analysis the basic parameters of the " $V$ " method and the new pillar method of excavation

\begin{tabular}{|c|c|c|c|}
\hline Basic parameters & $\begin{array}{c}\text { "V“" } \\
\text { method } \\
\text { (designed) }\end{array}$ & $\begin{array}{c}\text { "V"' } \\
\text { method } \\
\text { (real) }\end{array}$ & $\begin{array}{c}\text { Improved } \\
\text { "V" } \\
\text { method }\end{array}$ \\
\hline $\begin{array}{l}\text { Phase I - Construction of an excavation corridor - Pro- } \\
\text { gress (m/shift) }\end{array}$ & 1.00 & 1.00 & 2,00 \\
\hline $\begin{array}{l}\text { Phase I - Construction of as excavation corridor - Pro- } \\
\text { gress ( } \mathrm{m} / \text { day) }\end{array}$ & 3.00 & 3.00 & 6,00 \\
\hline Phase II - Getting coal - Deviation (m/shift) & 2.00 & 1.50 & 2,00 \\
\hline Phase II - Getting coal - Deviation (m/day) & 6.00 & 4.50 & 6,00 \\
\hline Height of the excavation (m) & 5.00 & 5.00 & 6,00 \\
\hline Excavation width (m) & 8.50 & 8.50 & 7,70 \\
\hline $\begin{array}{l}\text { Surface of cross-sectional area of the excavation in } \\
\text { progress }\left(\mathrm{m}^{2}\right)\end{array}$ & 8.50 & 8.50 & 16,15 \\
\hline $\begin{array}{l}\text { Surface of cross-sectional area of the excavation in } \\
\text { deviation }\left(\mathrm{m}^{2}\right)\end{array}$ & 33.97 & 33.97 & 30,05 \\
\hline Volume mass of coal $\left(\mathrm{t} / \mathrm{m}^{3}\right)$ & 1.33 & 1.33 & 1,33 \\
\hline The coefficient of utilization & 0.70 & 0.70 & 0,90 \\
\hline $\begin{array}{l}\text { The capacity of excavation in progress - phase I } \\
\text { (t/shift) }\end{array}$ & 11.31 & 11.31 & 42,96 \\
\hline The capacity of excavation in progress - phase I ( $\mathrm{t} /$ day) & 33.92 & 33.92 & 128,88 \\
\hline $\begin{array}{l}\text { The capacity of excavation in deviation - phase } \\
\text { II }(\mathrm{t} / \mathrm{shift})\end{array}$ & 63.25 & 47.44 & 71,94 \\
\hline $\begin{array}{l}\text { The capacity of excavation in deviation - phase II } \\
\text { (t/day) }\end{array}$ & 189.76 & 142.32 & 215,82 \\
\hline The capacity of excavation in total - phase I+II (t/shift) & 74.56 & 58.74 & 114,90 \\
\hline The capacity of excavation in total - phase I+II (t/day) & 223.67 & 176.23 & 344,70 \\
\hline $\begin{array}{l}\text { Number of workers per shift on excavation in progress } \\
\text { - phase I (wage) }\end{array}$ & 4 & 4 & 4 \\
\hline $\begin{array}{l}\text { Daily number of workers on excavation in progress - } \\
\text { phase I (wage) }\end{array}$ & 12 & 12 & 12 \\
\hline $\begin{array}{l}\text { Number of workers per shift on excavation in deviation } \\
\text { - phase II (wage) }\end{array}$ & 4 & 4 & 4 \\
\hline $\begin{array}{l}\text { Daily number of workers on excavation in deviation - } \\
\text { phase II (wage) }\end{array}$ & 12 & 12 & 12 \\
\hline The effect on excavation in progress - phase I ( $\mathrm{t} /$ day) & 2.83 & 2.83 & 10,74 \\
\hline The effect on excavation in deviation - phase II (t/day) & 15.81 & 11.86 & 17,98 \\
\hline The effect on excavation in total - phase I+II ( $t /$ day) & 9.32 & 7.34 & 14,36 \\
\hline
\end{tabular}


Figure 3 shows the DH L600 multipurpose loader of the German manufacturer Deilmann-Haniel Mining Systems GmbH with the additional equipment, and Table 2 shows the characteristics of the DH L600 and DH L1200 machines.

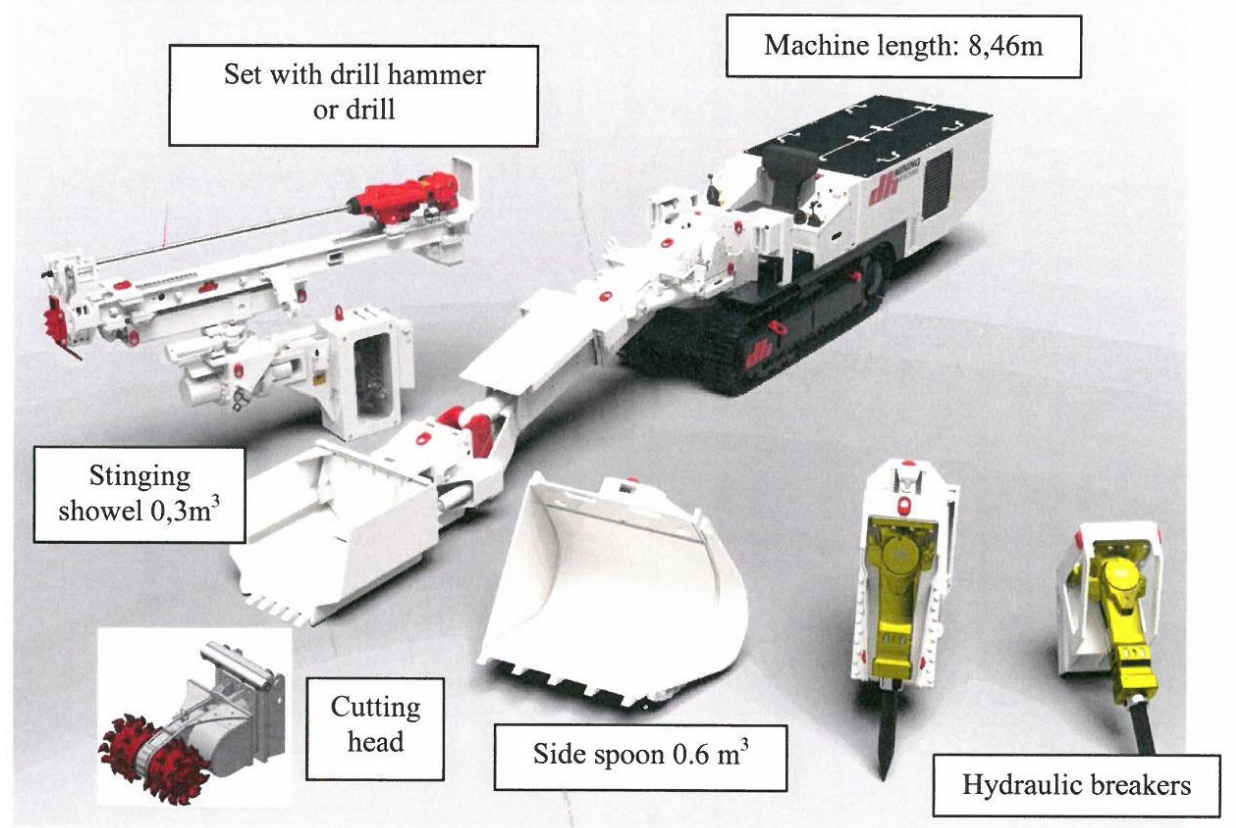

Figure 3 DH L600 multifunctional loader with accessories

Table 2 Characteristics of the DH L600 and DH L1200 machines

\begin{tabular}{|c|c|c|c|}
\hline \multicolumn{2}{|c|}{ Parameters of the loader } & dh L 1200 & dh L 600 \\
\hline \multicolumn{2}{|c|}{ Power of the engine } & $75 \mathrm{~kW}$ & $55 / 63 \mathrm{~kW}$ \\
\hline \multicolumn{2}{|c|}{ Pump capacity } & $2301 / \mathrm{min}$ & $145 \mathrm{l} / \mathrm{min}$ \\
\hline \multirow{2}{*}{ Volume } & Box-shovel & & $0.3 \mathrm{~m}^{3} / 0.6 \mathrm{~m}^{3}$ \\
\hline & Side shovel & $1.2 \mathrm{~m}^{3}$ & $0.3 \mathrm{~m}^{3}$ \\
\hline \multicolumn{2}{|l|}{ Driving speed } & $1,3 \mathrm{~m} / \mathrm{s}$ & $1.15 \mathrm{~m} / \mathrm{s}$ \\
\hline \multicolumn{2}{|c|}{ Overcoming of the rise } & $\pm 20^{\circ}$ & $\pm 20^{\circ}$ \\
\hline \multirow{2}{*}{$\begin{array}{l}\text { Transverse } \\
\text { inclination }\end{array}$} & Box-shovel & & $\pm 8^{\circ}$ \\
\hline & Side shovel & $\pm 8^{\circ}$ & $\pm 8^{\circ}$ \\
\hline \multirow{2}{*}{$\begin{array}{l}\text { The effect of } \\
\text { loading }\end{array}$} & Box-shovel & & $0.45-0.6 \mathrm{~m}^{3} / \mathrm{min}$ \\
\hline & Side shovel & $1.8-2.4 \mathrm{~m}^{3} / \mathrm{min}$ & $0.9-1.2 \mathrm{~m}^{3} / \mathrm{min}$ \\
\hline \multirow{2}{*}{ Length } & With box-shovel & & $8050 \mathrm{~mm}$ \\
\hline & With side shovel & $6800 \mathrm{~mm}$ & $7780 \mathrm{~mm}$ \\
\hline
\end{tabular}


Continuation Table 2

\begin{tabular}{|l|l|l|l|}
\hline \multicolumn{2}{|l|}{ Width } & $1560 \mathrm{~mm}$ & $1200 \mathrm{~mm}$ \\
\hline \multirow{2}{*}{ Height } & Without a protective roof & $1355 \mathrm{~mm}$ & $1200 \mathrm{~mm}$ \\
\cline { 2 - 4 } & With a protective roof & $1961 \mathrm{~mm}$ & $1994 \mathrm{~mm}$ \\
\hline \multirow{2}{*}{ Weight approx. } & $14000 \mathrm{~kg}$ & $10800 \mathrm{~kg}$ \\
\hline \multirow{2}{*}{ Ground pressure } & Machine space & $0,12 \mathrm{MPa}$ & $0,1 \mathrm{MPa}$ \\
\hline \multirow{2}{*}{ Free height } & Track shoe & $350 \mathrm{~mm}$ & $341 \mathrm{~mm}$ \\
\hline \multirow{2}{*}{ The angle of deflection of the working branch } & $2 \times 20^{\circ}$ & $250 \mathrm{~mm}$ \\
\hline Pace of telescopic arm & $900 \mathrm{~mm}$ & $2600 \mathrm{~mm}$ \\
\hline \multirow{2}{*}{ Unloading height } & With box-shovel & & $2899 \mathrm{~mm}$ \\
\cline { 2 - 4 } & With side shovel & $2157 \mathrm{~mm}$ & $3370 \mathrm{~mm}$ \\
\hline \multirow{2}{*}{ Excavation depth } & Box-shovel & & $569 \mathrm{~mm}$ \\
\cline { 2 - 4 } & Side shovel & $600 \mathrm{~mm}$ & $616 \mathrm{~mm}$ \\
\hline \multirow{2}{*}{ Penetration force } & Box-shovel & - & $40 \mathrm{kN}$ \\
\cline { 2 - 4 } & Side shovel & $71 \mathrm{kN}$ & $59 / 46 \mathrm{kN}$ \\
\hline Penetration force (horizontal) & $150 \mathrm{kN}$ & $100 \mathrm{kN}$ \\
\hline
\end{tabular}

\section{CONCLUSION}

Under the complex conditions of exploittation in coal deposits, the excavation of coal seams of medium and large thickness is carried out, mainly by the pillar excavation methods, with blasting technology, manual loading of excavation and its removal with grass conveyors.

Based on the analysis of the applied excavation systems in the mines, it is ob-vious that modernization and modernization the excavation system must be carried out in order to be more economically and safely mined. The acquired excavation experience in the current active deposits determines the continued application of pillar excavation methods, but with the wider introduction of modern equipment and mechanization of technological phases on excavations.
A detailed analysis has shown that the methods of mechanized wide foreheads can be introduced only in some parts of the coal deposits of the "Soko" and "Štavalj" mines.

The new method, which is the subject of this paper, can be applied under the conditions of most of active underground mines, which will greatly improve technical parameters and economic performances.

\section{REFERENCES}

[1] Ivković M., Janošević P.: Feasibility Study for Increase the Coal Production, Application of the New Excavation Method - Mine "Strmosten", Resavica 2016 (in Serbian) 
[2] Miljanović J.: Effective Factors in the Realization of the Foreseen Coal Production in the Mines With Underground Exploitation of the Republic of Serbia, Jurnal Mining Works No. 1/2001, Bor, 2001.
[3] Stjepanović M.: Strategic Approach to Planning Development and Production of Mineral Resources in the Mining Sector of Serbia, Journal Mining Works No. 1/2002, Bor, 2002.

[4] Technical Documentation of PC UCM Resavica (in Serbian) 